Катерина ЮДОВА-РОМАНОВА

\title{
ВОГНЯНІ ЗАСОБИ ДИЗАЙНУ СЦЕНІЧНОГО ПРОСТОРУ
}

\author{
Статтю присвячено дослідженню принципів дизайнерського оформлення сиенічного простору \\ вогняними засобами від витоків до сучасного стану. \\ Ключові слова: сиенічний дизайн, ритуальний вогонь, ілюмінація, феєрверк, піротехніка, вогняне \\ moy.
}

Статья посвящена исследованию принщипов дизайнерского оформления сиенического пространства огненными средствами от истоков до современного состояния.

Ключевые слова: сиенический дизайн, ритуальный огонь, иллюминация, фейерверк, пиротехника, огненное шоу.

The article is about a study of the principles of designing the stage space with fiery means from the origins to the present state.

Key words: stage design, ritual fire, illumination, fireworks, pyrotechnics, fire show.

Предметне коло інтересів сучасних дизайнерів - створення закономірно впорядкованого предметно-просторового середовища для задоволення естетичних потреб людей у різних сферах їх практичної життедіяльності. Особливим різновидом сфери дизайнерської діяльності є сценічний дизайн. При цьому сценічний дизайн, несучи в собі родові ознаки дизайну - спрямування художньої проектно-конструкторської діяльності на створення і оформлення предметного середовища, має принципову відмінність від інших видів дизайну. Сценічний дизайн передбачає конструювання такого простору, в якому відбувається візуальна дія. В організації цього простору поряд iз художником-дизайнером можуть брати участь актори, режисери, композитори, хореографи, архітектори та ін.

Сучасний сценічний дизайн належить до тих видів мистецтва, що в останні десятиліття активно та різновекторно розвиваються. Відображаючи різноманіття концепцій сучасного мистецтва, його образно-змістовні та формально виразові якості, сценічний дизайн $є$ яскравим синтетичним явищем, у якому знаходять віддзеркалення характерні художні тенденції часу. У наш час сценічний дизайн не просто визначає форму мистецького об'єкта або його функції. Він перетворився у своєрідну мистецьку мову, i, як будь-яку мову, його треба як слід вивчити, щоб використовувати максимально ефективно.

Проблеми національної складової вітчизняного дизайну порушуються у наукових розвідках В. Даниленка, Ю. Дяченко, І. Грицюк, О. Гребінник, О. Гладун, А. Бредихина, В. Косіва, М. Станкевича. Окремі аспекти теорії, історії та практики українського сценічного дизайну розглядались теоретиками і практиками мистецтва 3 точки зору його ролі у постановках творів сценічного мистецтва: аспект історичної еволюції - В. Берьозкін, І. Вериківська, Г. Веселовська, Д. Горбачов, Н. Срмакова, Н. Заболотна, О. Клековкін, Р. Коломієць, Н. Корнієнко, О. Красильникова, А. Липківська, Ю. Станішевський, В. Фіалко та ін.; сучасного стану - О. Ковальчук, О. Красильникова, О. Клековкін, О. Островерх, С. Триколенко та ін.; взаємозв'язків українського сценічного дизайну та світового мистецького процесу - О. Антонова, Т. Астафьєва, Т. Бачеліс, О. Боньковська, Н. Владімірова, В. Гайдабура, Л. Гітельман, М. Громов, Н. Ізвєков, Д. Ісмагілов, О. Клековкін, Н. Корнієнко, А. Нікітіна, Шеповалов Т. Шехтер та ін. Питання технічного оснащення як інструмента художньої виразності та засобу втілення творчого замислу постановників сценічних творів розглядають В. Базанов, В. Козлінський, Л. Дмітрієв, Л. Предславич, М. Ратімов тощо. Осмислен- 
ню власного практичного досвіду українськими сценографами присвячені праці Д. Боровського, М. Левитської, Д. Лідера, А. Петрицького, М. Френкеля та інших. Всі ці дослідження стали вагомим внеском у розвиток теорії та історії не лише вітчизняного, а й світового мистецького процесу. Натомість можна стверджувати, що у вітчизняній науці бракує наукового дослідження, присвяченого вітчизняному сценічному дизайну як особливому різновиду дизайну, де застосування вогню є провідним способом візуалізації художніх образів.

У цьому контексті постає актуальна потреба реалізувати мистецтвознавче дослідження, метою якого $є$ дослідити принципи художнього оформлення сценічного простору пірозасобами.

Найдавніші сліди застосування вогню людиною виявлені на стоянках синантропів ${ }^{1}$. Імовірно, що найдавніші люди навчилася послуговуватися вогнем раніше, ніж добувати його: використовувався вогонь лісових згарищ, пізніше людина навчилася переносити та підтримувати цей природний вогонь на стоянках $[1,116]$. Життедайна сила вогню зумовила релігійну традицію поклоніння йому та зробила частиною багатьох культових ритуалів.

Найпоширеніший і за всієї імовірності найбільш древній вид ритуального вогню - багаття. Воно фігурує майже без винятку у календарних обрядах всіх народів та у деяких релігійних святах, зокрема, у багатьох християнських. Характерна риса ритуальних вогнів, особливо багать, - ix суспільний характер. Навколо вогню завжди збирається колектив: у сільській місцевості - це все село або ж частина його жителів - куток; у містах це міська громада, населення - вулиці, кварталу, приходу. Об'єднувальна риса «вогняних» обрядів - демократичні, колективні, масові, шумні веселощі. Друга характерна риса «вогняних» обрядів - віра в чудодійну життєдайну силу полум'я, до якого треба було доторкнутися. Звідси, мабуть, і походить звичай перестрибувати через багаття. Загалом багаттям та іншим ритуальним вогням народ завжди приписував різні доброчинні функції: продуктивні, очищувальні, цілющі. Теплом, світлом від багаття та віруваннями у ритуальну чудодійну силу вогню зумовлювалось центральне композиційне розміщення багаття.

При цьому важлива й естетична насолода глядачів від споглядання полум'я. Видовищно-чаруюча сила натурального вогню багато в чому криється у його дієвій імпровізаційності. Непередбачуваний, раптовий характер формотворення та колористики зумовлює бажання глядача якомо- га довше спостерігати за візуальним огнненним об'єктом. Окрім багать, до таких об'єктів можна віднести й інші: наприклад, розпечене вугілля, смолоскипи, свічки, опудала, різдвяні поліна тощо. Всі вони містять в собі в тій чи іншій формі вогняну складову, але різняться за культурним, сценічно-мізансценічним та дизайнерським призначенням.

В Іспанії, в басків, на Балканському півострові в болгар та в зоні колишнього змішаного розселення болгар і греків відомий звичай ходіння босоніж по гарячому вугіллю (болг. «нестинарство»), який, як припускають дослідники, пов'язаний 3 культом вогню. Надвечір або вночі у музичному супроводі на розсипаному долі у формі сонця-кола розпеченому вугіллі, що слугує мерехтливим жовто-червоно-чорним тлом, виконуються босоніж ритуальні танці.

Широко відомий в різних народів вид ритуального вогню - смолоскип. Спочатку це була головешка, вийнята $з$ будь-якого багаття, згодом - 3 ритуального вогнища. Під час святкових веселощів вихоплені з вогню палиці, поліна в руках учасників обряду описували кола в повітрі, з ними хлопці бігали один за одним та за жінками та дівчатами, змушуючи їх підскакувати вище - щоб високими вродилися посіви» і т.п. Ритуальні факельні процесії навколо полів, обійсть, хлівів тощо відомі у різних місцях Європи і влаштовувались у різні дні язичницьких та християнських календарних свят. Згодом, коли релігійна складова стала втрачати свою системоутворювальну функцію, факельні ритуальні процесії трансформувались у веселу розвагу молоді із факельною ходою. 3 часом почали застосовувати різноманітні ліхтарі. Так, приміром, відомо про оригінальне дизайнерське рішення саморобних ліхтарів для святкової процесії: «всередині видовбаного і надітого на високу палицю гарбуза встановлювали свічку, в гарбузі вирізали отвори, що імітують людські очі, рот, астральні знаки і т. п.» (перекл. наш - К. Ю.-P.) $[1,121]$. Таким чином, можна розглядати використання смолоскипів не лише як складову дизайну самої процесії як театралізованого заходу, а й окремо, як власне дизайн освітлювального приладу.

У системі релігійного світосприйняття людиною ритуальний вогонь має містити чудотворну складову і тим відрізнятися від повсякденного, можна сказати, побутового вогню. Це має бути «чистий», «божественний» вогонь. Недарма у стародавній Олімпії перед початком чергових Олімпійських ігор запалюють смолоскип за допомогою фокусації сонячного променя у вгнутому 
дзеркалі. Далі вогонь смолоскипами переноситься до місця ігор, де він горить невгасимим полум'ям упродовж змагань. Також за допомогою смолоскипів переносять вогонь зі священних військових могил, щоб запалити невгасимий вогонь на нових поминальних місцях.

Слід зауважити, що якщо багаття і розпечене вугілля можна класифікувати як засоби статичного сценічного вогняного дизайну, то застосування смолоскипів та їх сучасних модифікацій - до рухомого.

У XX ст. у багатьох календарних обрядах традиційні вогні замінювалися свічками, які стали іноді єдиними джерелами світла. Свічка ввійшла в усі ритуали християнської церкви. Для свята Стрітення свічка стала головним і необхідним атрибутом. Як і від інших ритуальних вогнів, від стрітенських свічок чекали чудодійної сили. Слід зауважити, що за таких вірувань використання свічок в обрядах зумовлене більш прагматичними чинниками - магічно-змістовним та утилітарно-освітлювальним призначенням, аніж дизайнерським конструюванням середовища. Але, навіть за умови зміщення акцентів призначення, свічка залишається вагомою складовою дизайнерського вирішення багатьох обрядів. Звернімо також увагу на локальність заходів із застосування свічок щодо їх розмірів та кількості учасників у порівнянні з багаттями, розпеченим вугіллям, смолоскипами та опудалами.

До особливої групи ритуальних вогнів треба віднести ті, що їх традиційно розпалюють під час карнавалу (Масляної) в усіх без винятку народів Європи. Карнавал - це складний комплекс обрядових дійств, виконуваних у християнському світі перед великим постом. Апофеозом будь-якого карнавалу є знищення, переважно спалення, оnyдала - символічної фігури персонажа: «зими», «смерті», «м'ясоїду» тощо. При цьому художнього вирішення вимагало як створення самого опудала, так і сценічного простору для самого театралізованого дійства. Як правило, знищенню підлягало солом'яне опудало жінки, яке розміщували у центральній частині карнавального майдану. У деяких випадках простежується варіативність карнавальної традиції: змінюються календар святкувань та самі персонажі. Так в Іспанії та Португалії під час різдвяно-новорічних свят спалювали опудала старого і старої, в Англії спаленню підлягав Старий рік - гротескна солом'яна фігура, яку пізніше замінили на смоляні бочки та старі човни. У Шотландії на 1 листопада засуджували до спалення «відьму», у поляків на страсно- му тижні згорав на вогнищі «Іуда», а в Іспанії в день св. Йосипа (19 березня) на згадку про традицію відвертали всяку нечисть палаючими сосновими гілками, в деяких місцевостях (у Валенсії) на вогнище відправляли ганчір'яну ляльку, що втілювала образ непопулярного державного діяча. Доповненням до карнавального багаття було буйство інших вогнів - смолоскипів, вогняних дисків, феєрверків, петард, святкової ілюмінації.

Багатьом народам Європи відоме як складова ритуального обряду так зване різдвяне поліно. Товстий пень, колода чи велике поліно палало в пічці або каміні, починаючи зі Святвечора, впродовж усіх наступних дванадцяти днів і ночей. У слов'янських народів відомі звичаї, які можна сприйняти за ослаблені, згладжені сліди обряду: на дванадцятидення на передпіччі хлібної печі спалювали скіпки, дранки, намагаючись, щоб цей вогник не згас упродовж святкового дня; уважали, що тим самим захищаються від нечистої сили. 3 точки зору дизайну різдвяне поліно можна трактувати радше як складову дизайну інтер'єру, ніж як сценічний дизайн.

Ритуальні вогні ввійшли в сучасні обряди та інші святкові заходи різного гатунку. Впродовж історичного розвитку, у різних ситуаціях, деякі функції вогню нівелюються, інші, навпаки, розвиваються. Але нині мало не кожне свято має у своєму візуальному образі художнє дизайнерське рішення, де значне місце посідають ілюмінація, феєрверки, петарди та інші піротехнічні прийоми.

Беручи витоки у культовій обрядовості, в сучасному сценічному дизайні вогонь використовується у поєднанні з досягненнями у галузі науки та техніки. Розділ техніки, пов'язаний із виготовленням вибухових і займистих сумішей, сигнальних вогнів, ракет, феєрверків отримав назву «піротехніка». Нині вона широко застосовується як у військовій справі, так і у культових та театрально-видовищних заходах.

Започатковане в Азії багато тисяч років тому мистецтво створення вогню і управління ним - icнує 3 давніх часів. Китайці винайшли свого часу порох для влаштування святкових ритуальних феєрверків - святкових різнокольорових декоративних вогняних ефектів, яким під час релігійних церемоній відганяли злих духів. Згодом феєрверки стали запускати під час фестивалів та інших цивільних свят. У Європі феєрверки вперше з'явилися в середньовічній Італії.

Перші згадки про влаштування феєрверків у Росії датуються 1389 р. - ці т. зв. «потішні вогні» для Дмитра Донського з Німеччини привезли куп- 
ці. Відтоді феєрверки влаштовувалися дуже епізодично й імпортувалися переважно з Німеччини. Перші російські майстри феєрверків 3'явилися близько 1545 p. - тоді був заснований Стрілецький полк, при якому перебував на службі «пороховий завідувач»: він сам придумував, виготовляв і запускав феєрверки.

Традиційним елементом урочистостей феєрверк стає ближче до XVII ст. Святкові заходи Новий рік, Масляна, святки, народні гуляння, придворні урочистості за Петра I (1672-1725) не обходилися без феєрверків. Замість звичних нам вогняних каскадів із зірок і куль майстри 3 піротехніки XVII ст. «випалювали» в небі вогняні малюнки із зображенням палаців, фортець, альтанок, епізодів з біблійної історії, сцен історичних військових баталій.

Пригадаймо грандіозне святкування 3 феєрверком перемоги у Північній війні та Ніштадтського миру в Петербурзі 22 жовтня (2 листопада) 1721 р. Скористаємось для цього спогадами свідка подій - М. І. Кашина²: на Петербурзькому острові навпроти Сенату був збудований храм Януса у вигляді великого фігурного театру й прикрашений різнокольоровими вогнями; на воротах храму вогняним гнотом викладено план: намальовано Януса древнього, миротворного. Навпроти храму було поставлено дві фігури: перша символізувала Петра Великого, друга - короля Швецького. Далі біля храму гнотом за планом було викладено піраміди, колеса та різні вогняні фігури. До храму було протягнуто мотузку від сенатської галереї, на кінці якої був прикріплений орел. Організацією всіх приготувань опікувався сам цар та двоє бомбардирів. Після зібрання всього генералітету в Сенаті, від них його величності за його зусилля на благо Російської держави було принесено титул імператорський із визнанням його батьком вітчизни та государем всемилостивим. О 12 годині ночі сам імператор підпалив орла, який полетів просто до храму Януса і запалив план зі статуєю, що почала горіти; після цього фігури пішли з розпростертими руками і зачинили ворота Януса, і з тих воріт раптово вилетіло тисячу ракет, і потім у напрямку міста з гармат на плаваючих по річці Неві галер розпочалась стрілянина, що нагадувала грім i блискавки і продовжувалась 3 годину. Опісля підпалили два плани - на одному зображувався корабель, що прямує в гавань 3 написом «Конец дело венчало»; на іншому - корони Російська і Швецька поєднанні на столі написом «Соединение дружбы». Після згорання планів розпочалася дивовижна вогняна потіха 3 пірамідами, схожими на діаманти, а нагорі піраміди корона Російська, а на другій корона Швецька, і тривала потіха години чотири [3].

Після Петра I царська родина продовжувала розвивати традицію грандіозних феєрверків. Ось як описує М. І. Пиляєв ${ }^{3}$ святкові заходи влаштовані імператрицею Катериною II з нагоди приїзду у 1770 р. в Росію принца Генріха, брата короля прусського: «Особливо чудовим був маскарад, даний для нього в Царському Селі <..>. У семи верстах від Петербурга, вони [гості] проїхали крізь великі тріумфальні ворота, чудово освітлені. Потім на шляху через кожні сім верст стояла піраміда, майстерно ілюмінована, і проти неї готель; у кожному з них сиділи люди різних націй, які танцювали і грали на інструментах. На Пулковській горі був представлений Везувій, що вивергав полум'я, - це виверження тривало цілу ніч. Від Пулковської гори до Царського Села стояли дерева, на яких висіли різнокольорові ліхтарі у вигляді гірлянд. Після прибуття в Царське Село, палац був освітлений giorno ${ }^{4}$; після танців, за пострілом з гармати, бал припинився, разом 3 ним згасли і всі вогні в палаці; потім всі стояли біля вікон і дивились чудовий феєрверк. Новий гарматний постріл подав сигнал, і миттю знову засвітився палац; після цього відбулась розкішна вечеря» (переклад наш - К. Ю.-Р.) [5]. Досвід феєрверкового театру згодом використовувався для створення сценічних ефектів у театральних постановках і балаганних феєріях.

Феєрверки влаштовувалися не лише в столицях. Їх спостерігали жителі Казані, Полтави, Києва та інших губернських міст. У Києві часто влаштовували «потішні вогні» на воді - феєрверки, які запускали $з$ причалу або з човна, що розташовувався неподалік від берега. Поверхня води використовувалася як дзеркало, що відображає і примножує феєрверк, який від цього ставав пишнішим та більш видовищним [4].

Ілюмінація стала важливою складовою святкового світло-вогняного оформлення нічного Києва. Так 1870-ті рр. увійшли в історію київського побуту як епоха фантастично розкішних нічних гулянь 3 піротехнічними вогнями святкової ілюмінації по обох берегах Дніпра. Для дизайну міста використовували свічки, виставлені на вікнах, запалені сальні плошки на брівці тротуару та на карнизах воріт, смоляні бочки, що їх підпалювали на площах, горах і берегах Дніпра, прозорі картини у вітринах магазинів, підсвічені вензелі й символічні зображення на транспарантах. У дні великих торжеств у таємничій нічній далечині ви- 
никали світлі абриси високих дзвіниць, будинків, мерехтливі лінії вулиць розцвічувалися вогненними фонтанами феєрверків, що їх запускали в приватних садибах. Так, 28 червня 1814 р. $з$ нагоди маніфесту про укладання миру із Францією, пише митрополит, були святково оформлені ілюмінацією Софійська й Лаврська дзвіниці. На першій було запалено - 100, а на другий - 200 плошок. На вшановуваннях коронованих осіб кількість освітлювальних плошок обчислювалася тисячами [2].

Слід зауважити, що з 1860 р. у вогненних потіхах стали широко застосовуватися й бенгальські вогні. Про ілюмінації на честь приїзду Олександра II влітку 1869 р. у газетs «Кіевлянинъ» зазначалось, що Хрещатик і спуски до нього з Липок i зі Старого міста були «блискуче ілюміновані плошками, ліхтариками, вензелями й транспарантами. Час від часу в різних місцях запалювали бенгальські вогні, що особливо приваблювали публіку» (переклад наш - К. Ю.-Р.) [цит. за: 2].

Улітку 1878 р., під час російсько-турецької війни, в день іменин цариці у Києві по обох берегах Дніпра було влаштовано вогняне шоу, яким насолоджувались глядачі, курсуючи річкою на п'ятьох пароплавах, та десятки тисяч спостерігали його фрагментарно з ланцюгового мосту та схилів Дніпра. Відповідно до задуму організаторів за сигналом з пароплава в деяких місцях засвічувалась ілюмінація з використанням смоляних діжок, запускались феєрверки та запалювались бенгальські вогні, а біля майстерні Товариства пароплавства на Трухановому острові вогнями було викладено вензель государині імператриці [2].

У XIX ст. у Києві стали досить популярними «nрозорі картини» 3 алегоричними й геральдичними сюжетами. Вони писалися прозорими фарбами на тонкому проолісному полотні й висвітлювалися ззаду сальними плошками. Ці ілюміновані транспаранти мали значні розміри, досягаючи в довжину до 30-ти, а у висоту - до 12 метрів.

3 появою електричного освітлення значення вогняних ефектів у дизайні театрально-видовищних заходів не зменшилось. Навпаки, індустріалізація промислового виробництва для створення вогняних ефектів динамічно розвивається. Сьогодні можна стверджувати про потужний художній потенціал сучасної піротехнічної індустрії. Розширюється асортимент кольорів та форм горючих наповнювачів та програмне забезпечення піротехніки.

Сценічна (концертна) піротехніка - це техніка, що застосовується для створення піротехнічних ефектів у закритих приміщеннях. Харак- терною рисою сценічної піротехніки є відносно низька температура горіння та мала кількість шкідливих продуктів згоряння (дим, запах тощо). Сценічна піротехніка використовується для проведення сценічного феєрверка - піротехнічного супроводу театралізованого заходу на сценічному майданчику.

Сценічну піротехніку можна розділити на три основних групи: ефекти, що створюють полум'я, кольорові димові ефекти, іскристі ефекти. Режим застосування піротехнічних ефектів, що їх можна застосовувати в закритих приміщеннях в тому числі і на закритих сценічних майданчиках, залежить від висоти підйому і радіуса падіння іскор, температурного режиму ефекту, наявності займистих елементів у декораціях, близькості людей, світлових і звукових приладів, а також ступеня вентиляції приміщення.

Сучасні феєрверки традиційно поділяються на висотні, паркові та наземні. Висотні феєрверки зазвичай завершують програму піротехнічного показу і стають яскравим фінальним акцентом. Для надання висотному феєрверкові казковості, насиченості і різноманітності в процесі показу, піротехніки поєднують вироби з різними образотворчими ефектами - у вигляді кулі, пальми, серця, хризантеми, півонії або будь-якої іншої хитромудрої фігури.

Феєрверк парковий - феєрверкове видовище, в якому використовуються піротехнічні вироби, котрі після свого запуску залишаються на землі, але випускають угору (на висоту до 50-60 м) вміщені в них піроелементи. Парковий феєрверк $\epsilon$ оптимальним рішенням для проведення заходів на невеликому майданчику, де відстань до глядачів становить не більше 50 м.

Окреме місце серед паркових феєрверків посідають денні салюти. В них зоровий ефект, що супроводжується тріскотінням та вихлопами, створюється шляхом появи траєкторій різнокольорового диму: червоного, жовтого, синього, зеленого, оранжевого, пурпурного, білого. Деякі 3 денних салютів вистрілюють парашутами з різнокольоровими вимпелами, на яких спускаються заряди, малюючи при цьому в повітрі різнокольорові димові лінії.

Іноді, зважаючи на обмеженість сценічного простору, можна зробити яскраве і різноманітне піротехнічне шоу, використовуючи лише наземні феєрверки. Феєрверк наземний - це феєрверкова вистава, для якої використовуються наземні піротехнічні вироби, що працюють, не відриваючись від землі, на висоті до 10 м: спалахи, фонтани, 
піротехнічні фігури, динамічні колеса, вогняні написи і логотипи, вогнепади та ін. У процесі роботи іскри, що випускаються піроелементами, створюють задану фігуру. Піроелементи можуть бути закріплені як на статичній конструкції (сонце, ялина, зірка) так і на динамічній (млин, колесо). Групуючи фігури різних видів, можна створити прекрасну «живу» вогненну картину, а іноді й вогняну виставу - піротехнічне шоу. Особливий різновид наземного феєрверка - феєрверк водний. Тут використовуються водні піротехнічні вироби, що вистрілюють у воду або запускаються з води.

За впливом на аудиторію мало що може зрівнятися з вогняними гарматами (вогнеметами), які вивергають довгі язики відкритого сліпучого полум'я на висоту 3-4 метрів. Вогняне шоу чудово поєднується з іншою сценічною піротехнікою, лазерами та світловими ефектами.

Вогонь в акторському виконанні - завжди вражаюче, приголомшливе, неочікуване й оригінальне видовище. У поєднанні з музикою, хореографією, цирковими номерами, світлотехнікою він справляє незабутнє враження. При цьому застосовується піротехнічний акторський реквізит: різного роду піробластери, піродробовики, пірокомети, пірогармати, а також гітари-вогнемети чи печатки-вогнемети поруч із петардами, бенгальськими вогнями та вогняними ліхтариками. Не менш естетично виразно на сцені виглядають і пірокостюми - сценічний одяг виконавців 3 піроелементами.

Сьогодні піротехніка широко використовується як один 3 візуальних засобів сценічного оформлення театрально-видовищних заходів різного жанрового спрямування. При цьому простежується виокремлення в самостійні жанри сценічного мистецтва вогняних шоу-вистав (фаєр-шоу), в яких піротехнічні ефекти утворюють основний візуальний розвиток дії, та піромузичних шоу, де феєрверк та інші піротехнічні ефекти синхронізуються з музичними підйомами і спадами, наслідують настрій музики.

Жодним іншим ефектом неможливо так яскраво закцентувати потрібний сценічний епізод, як піротехнічним. 3 метою художнього поєднання піротехнічних ефектів із сценічною дією дизайнер-піротехнік обговорює постановочний план з режисером і пише максимально грунтовну партитуру, в якій враховується сумісність роботи ефектів у певний момент часу та інтенсивність зміни феєрверкових картин. Завдяки комп’ютерній системі управління можна 3 точністю запроектувати піросценарій, візуалізувати та за потре- би скорегувати його на комп’ютері за допомогою спеціального програмного забезпечення. Піротехнічний сценарій передбачає запис послідовних піротехнічних елементів, об'єднаних єдиною дією та назвою. Сценарій може бути написаний для піротехнічного концерту, піротехнічної сюїти або піротехнічної вистави.

Підсумовуючи вищезазначене, можна стверджувати, що традиційною складовою сценічного дизайну є вогняні ефекти. До витоків застосування у сценічному дизайні піротехнічних прийомів можна віднести ритуальні вогні: багаття, розпечене вугілля, смолоскипи, свічки, опудала, різдвяні поліна. Натомість можна віднести до первинних статичних засобів вогняного дизайну багаття, розпечене вугілля та спалення опудал, а смолоскипи - до динамічних. Щодо масштабності, слід зауважити, що свічки переважно застосовуються у менш локальних заходах у порівнянні з багаттям, розпеченим вугіллям, смолоскипами та опудалами. Щодо спалювання опудала, то карнавальна традиція вимагала дизайнерського вирішення як створення самої ляльки, так і конструювання предметно-просторового середовища для проведення театрально-видовищного дійства.

Вогонь як головна складова піротехнічного мистецтва створення вогню та управління ним широко застосовувався у Петровську епоху як домінантна складова театралізованих дійств. Для дизайну київських публічних святкових театралізованих заходів просто неба у XIX ст. часто застосовувались піротехнічні прийоми: ілюмінація оздоблення будинків, вулиць, берегів Дніпра свічками, плошками, смоляними бочками; феєрверки; підсвічувались прозорі картини у вітринах магазинів, висвічувались вензелі й символічні зображення на транспарантах.

Еволюціонуючи, сценічний вогонь тісно ввійшов у святкову традицію всіх народів світу. Багато нинішніх культових та цивільних свят супроводжуються ілюмінацією й феєрверками. Сьогодні дизайнери у співпраці 3 режисерами театрально-видовищних заходів різних жанрів широко застосовують піротехнічні ефекти.

Досліджуючи тему художнього конструювання як методу проектування предметно-сценічного середовища вогняними засобами, ми лише поверхово торкнулися питання витоків, особливостей історичної еволюції та сучасного стану, залишивши поза увагою конкретні приклади застосування вогню у сучасних театрально-видовищних постановках. Окреслений вектор подальших мистецтвознавчих досліджень засвідчують 
значимість і перспективність даної тематики наукової розвідки.

1. Синантроп - представник найдавніших викопних людей. Абсолютна давність - близько 400 тис. років.

2. Кашин Микита Іванович - російський мемуарист, рядовий, потім сержант російської армії перш. пол. XVIII ст.

3. Пиляєв Михайло Іванович ( 1842-1899) - російський письменник і журналіст, який збирав цікаві історії та анекдоти про петербурзьке життя XVIII - перш. пол. XIX ст.

4. Giorno (італ.) - день.

\section{Джерела та література}

1. Иванова Ю. В. Обрядовый огонь [Текст] / Ю. В. Иванова // Календарные обычаи в странах зарубежной Европы: исторические корни и развитие обычаев / ред. кол. : С. А Токарев (отв. ред.), И. Н Гроздова, Ю. В Иванова, С. Я. Серов. - М. : Наука, 1983. - С. 116-130.

2. Иллюминация [Текст] // Малая энциклопедия киевской старины / Анатолий Николаевич Макаров. - К. : Довіра, 2005. - C. 149-150.

3. Кашин Н. И. Поступки и забавы императора Петра Великаго (Запись современника) / Сообщ. и предисл. В. В. Майкова [Електронний ресурс]. - Санкт-Петербург : Типография И. Н. Скороходова, 1895. - 22 с. - В серии :
Памятники древней письменности. - Т. 110. - Режим доступу: http://memoirs.ru/ - Назва з екрана.

4. Потешные огни [Текст] // Малая энциклопедия киевской старины / Анатолий Николаевич Макаров. - Киев : Довіра, 2005. - С. 374-375.

5. Пыляев М. И. Эпоха рыцарских каруселей и аллегорических маскарадов в России [Електронний ресурс] // Исторический вестник, 1885. - Т. 22. - № 8. - С. 319-320. - Peжим доступу: http://memoirs.ru/ - Назва з екрана.

\section{References}

1. Ivanova, Yu. V. (1983). Ritual Fir. Calendar customs in the countries of Foreign Europe: historical roots and development of customs. S. A. Tokarev (Ed.). - Moscow : Nauka [in Russian].

2. Makarov, A. N. (2005). Illumination. Small encyclopedia of Kiev antiquity. - Kyiv : Dovira [in Russian].

3. Kashyn, N. Y. (1895). The deeds and entertainment of Emperor Peter the Great (Recording of a contemporary). Russian memoirs: Russia in the diaries and memoirs: site of Mikhail Voznesensky. - Retrieved from https://memoirs.ru/ texts/Kaschin1895.htm

4. Makarov, A. N. (2005). Amusement lights. Small encyclopedia of Kiev antiquity. - Kyiv : Dovira [in Russian].

5. Pylyayev, M.Y. The era of knightly carousels and allegorical masquerades in Russia. Russian memoirs: Russia in the diaries and memoirs: site of Mikhail Voznesensky. - Retrieved from https: //memoirs.ru/texts/Pyl_IV85_22_8.htm 